\title{
AN ANNOTATED LIST OF MYXOMYCETES FOUND IN THE NETHERLANDS, MOSTLY IN THE VICINITY OF DOORWERTH
}

\author{
N. E. NANNENGA-BREMEKAMP \\ (Doorwerth)
}

(received October 20th, 1960)

Since the publication of Dr. T. BRoexsmit's paper on Myxomycetes, which includes a list of the representatives of this group then known from the Netherlands (Ned. Kruidk. Arch., 1923: 315-327), and of that by A. M. Scholte (ibid., 1926: 155-162), only a few new finds have been reported.

In July 1953 Dr. W. K. H. Karstens kindly sent me an unpublished list of all the species of which he had seen specimens from the Netherlands; it comprised practically all finds that had been made up to that date, those of myself included. In total 130 species and varieties were enumerated, and of each of them the number of specimens seen by him was recorded. A few of those mentioned by Dr. Broeksmit, viz. Badhamia nitens, Physarum conglomeratum, Diderma radiatum, Didymium difforme var. comatum, Lamproderma columbinum, Cribraria microcarpa, $C$. splendens, Liceopsis lobata and Cornuvia serpula (in the order of the list) are not included in Dr. Karstens' list, either because the specimens were lost, or because the determination proved to be incorrect, and Arcyria globosa, one of the eight new indigenes mentioned by Scholte, proved to be $A$. cinerea (private communication). Eighteen species and varieties from Dr. Karstens' list were so far not found by me, whereas my list contains the names of sixtyeight species and varieties not mentioned by him. These species and varieties are marked with an asterisk (*) as they are regarded by me as new to the Netherlands.

I started collecting in August 1951, mostly in the vicinity of Doorwerth, and unless another locality is mentioned, the specimens were all collected in the area between Renkum and Oosterbeek, Wolfheze and the Rhine; the notes on the frequency apply to this area alone.

Quite a number of my Myxomycetes were obtained in "culture", i.e. on pieces of bark, either from dead or from living trees, or on fragments of dead wood that were soaked for a few hours in tap water, then placed in a dish on wet blotting paper and covered with plastic, the dish subsequently being kept at room temperature. Myxomycetes usually develop after a week or a fortnight, although some require about a month (e.g. some species of Licea).

The colour of the plasmodium is recorded only when the plasmodium was seen by myself; it is not necessarily the same as that given in the monographs.

The names are those used by Dr. G. W. Martin in the North 
American Flora, Vol. 1, part 1 (1948); where they differ from those used in the well-known monograph by the Listers, the name applied by the latter is added between brackets. These names are also mentioned in the alphabetical sequence, but there they are written in small type with a reference to the name used by Martin.

In due time I hope to describe my specimens more fully, citing the numbers of the collections; a start has already been made in "Notes on Myxomycetes IV" published elsewhere in this journal.

Amaurochaete cribrosa Sturgis of. A. tubulina

Am. fuliginosa (Sow.) Macbride

On practically undecayed coniferous wood; common. Plasmodium white, then carmine tinted, turning deep mulberry red, and finally black.

Am. tubulina (Alb. et Schw.) Macbride (A. cribrosa Sturgis)

In the same habitats as the preceding species, and often simultaneous with it; five collections. Plasmodium too like that of the preceding species.

Arcyodes incarnata (Alb. et Schw.) O. F. Cook (Lachnobolus congestus Lister)

On decaying wood; not rare. Plasmodium white.

* Arcyria carnea G. Lister

On decaying wood; not rare. Plasmodium white.

This species has apparently often been confused with others, especially with $A$. insignis, $A$. denudata and $A$. incarnata; in colour and size it is similar to an unexpanded $A$. incarnata. The capillitial net, however, has very fine meshes, a character which permits identification by the aid of a hand lens; further it is impossible to blow the firmly attached capillitium out of the cup. Various authors mention a close resemblance to $A$. cinerea, but this has never struck me.

Arc. cinerea (Bull.) Pers.

On decaying wood; very common. In dense colonies or scattered; in cultures usually scattered; either nearly white, dirty yellowish, beige, greenish, bluish or grey. Plasmodium white.

Arc. denudata (L) Wettst.

On decaying wood, rarely on leaves, but then usually near decaying wood; common. Plasmodium white.

Arc. ferruginea Sauter

Mostly on oak wood, on decaying stumps as well as on a living tree; on the latter about one meter from the ground; not rare. Plasmodium pink or salmon.

Arc. incarnata (Pers.) Pers. var. incarnata

On decaying wood, especially on fallen branches; very common. Plasmodium white.

* Arc. incarnata (Pers.) Pers. var. fulgens Lister

This variety is described as dark reddish brown and provided with firm stalks. As no mention is made of the capillitium, 
we may assume that this is similar to that of the type. If this surmise is correct, then I have collected the variety a few times only. However, a large number of specimens to which the description of the colour and of the stalks is applicable, cannot be placed here because of the capillitium, which has much smaller meshes, and expands therefore less strongly, of the cup, which is asymmetrical, and of the structure of the capillitium threads, which are thicker, more densely spinulose and partly reticulate. They represent apparently an undescribed species. Pending further study, I will mention it below as $A$. spec.

Arc. nutans (Bull.) Grev.

On dead wood, and sometimes on living trees; very common. Plasmodium white.

Arc. oerstedtii Rost.

On decayed beech and pine wood; once on a stump of an unknown tree; not rare. Pasmodium white.

Arc. pomiformis (Leers.) Rost.

* Arc. spec.

On decayed wood; very common. Plasmodium white.

See above under $A$. incarnata var. fulgens. Plasmodium white.

Badhamia affinis Rost. var. orbiculata G. Lister cf. B. orbiculata

Badh. foliicola Lister

On grass, dead leaves and pine needles; common; in some years in spectacular quantities. Plasmodium pale or deep yellow.

* Badh. lilacina (Fries) Rost. var. lilacina

Collected at Kortenhoef in a Sphagnum bog and on the brink of the small islands found in the large sheet of water there, where it proved to be common. The tufts of sporangia vary in colour from ash-grey to dusty rose. Plasmodium (of a specimen found on one of the islands) yellow.

I have marked this find with an asterisk, although the name occurs in the list of Dr. Karstens. Here, however, it was applied to a specimen collected by me at Ootmarsum, for which it can not be retained, as it is the type of my var. megaspora. The specimens collected in 1958 at Kortenhoef are therefore the first that are known from the Netherlands.

* Badh. lilacina (Fries) Rost. var. megaspora N.E.N-B. (Acta Bot. Neerl. 7: 184. 1958)

Known only from the marshy source of the "Poelbeek", Ootmarsum.

Badh. macrocarpa (Ces.) Rost.

Two collections only, one from the bark of a recently felled beech, the other from a dead fruit tree. Plasmodium white.

* Badh. orbiculata Rex (B. affinis Rost. var. orbiculata G. Lister)

On fallen bark of dead fruit trees; a few collections only. Plasmodium white. 
Badh. panicea (Fries) Rost.

On the bark of dead trees and on stumps; common. Plasmodium white.

Badh. utricularis (Bull.) Berk.

On dead wood, bark, Stereums and even on sand; common. Extremely variable in all its properties. Plasmodium deep yellow to orange.

* Badh. viridescens Meylan

Up to now known from Switzerland and Scotland only. Obtained once in culture from a yellow plasmodium on bark of a dead fruit tree; the collection consists of seven well developed sporangia and a few abnormal ones.

Brefeldia maxima (Fries) Rost.

My attention was asked for a large, white plasmodium on the Hemelse Berg near Oosterbeek by Dokter J. H. Broers, who had found it there the previous year too. According to his description there was such a quantity of plasmodium then, that it looked as if buckets of whitewash has been overturned and splashed about; later the plasmodium had moved up the tree trunks and the stems of herbaceous plants, where the sporangia developed in some parts a meter above the ground. Also collected by E. T. Nannenga on a large stump of Populus at Rijnauwen near Utrecht.

\section{Ceratiomyxa fruticulosa (Mull.) Macbride}

On decaying wood; very common. Very variable in shape and colour. Plasmodium watery and white, ivory, salmon or rose.

* Cienkowskia reticulata (Alb. et Schw.) Rost.

On the bark of a fallen beech branch; collected only once. Plasmodium orange.

* Clastoderma debaryanum A. Blytt

On decaying oak wood piled up to be used as firewood; collected only once. Plasmodium watery white.

* Colloderma oculatum (Liert) G. Lister

Difficult to detect in the open, where I collected it once on moss on a living oak. Obtained in culture from mossy bark of birch. Plasmodium dark and opaque, brown.

* Comatricha cornea G. Lister et Cran

On bark of elm, only in culture. Plasmodium watery white.

Com. elegans (Racib.) Lister var. elegans

On decaying wood; not rare. Plasmodium watery white.

* Com. elegans (Racib.) Lister var. palens G. Lister

On decaying pine wood; once collected.

* Com. fimbriata G. Lister et Cran

On bark and wood of dead and living trees; very common.

Because of its small size it is easily overseen, but it may be found by turning fallen branches against the light, as then they stand out against the light background. Appears in most cultures. Plasmodium watery white. 
Com. flaccida (Lister) Morgan (Stemonitissplendens Rost.var.flaccida Lister) On coniferous stumps; common. Plasmodium white, pale yellow or yellow.

- Com. irregularis Rex ?

One specimen from a decaying beech stump seems to belong here; if the identification is correct, it is the first record for Europe. Plasmodium white.

Com. laxa Rost. var. laxa

On decaying wood, common. Plasmodium watery white.

- Com. laxa Rost. var. rigida Brandza

On dead wood; a few collections only.

* Com. longa Peck

Recorded from Europe up to now only from a glass-house near Berlin and from Roumania. Thrice collected by me; twice on the same beech stump, in consecutive years; once from another beech stump, a few kilometers from the first.

Com. nigra (Pers.) Schroet. var. nigra

On wood and bark; very common. Very variable. Plasmodium watery white.

Com. nigra (Pers.) Schroet. var. alta Lister

On fallen branches of lime and beech; a few collections only. Plasmodium watery white.

This variety is easily recognizable because the free ends of the capillitium threads in the basal part of the sporangium are distinctly thickened (clubshaped), and because the capillitium forms a flimsy tangle, which, when the sporangium dehisces, expandsin one direction to as much as ten times its original height.

Com. pulchella (G. Rab.) Rost. var. pulchella

On dead leaves and grass; very common. It is one of the few species which occur regularly on dead bracken leaves. Plasmodium watery white.

* Com. pulchella (C. Rab.) Rost. var. gracilis Lister

Collected once on a decaying beech stump covered with grass and dead leaves.

Com. tenerrima (M. A. Curt.) G. Lister

On old straw and on fallen branches; especially common on old straw. Plasmodium watery white.

Com. typhoides (Bull.) Rost.

On decaying wood; very common. Plasmodium watery white.

* Com. spec.

Close to C. acanthoides Alexopoulos (Mycologia 50: 55. 1958), but differing in the denser capillitium and in the spores, which are not spinose but warted. Truly "solitary" indeed; the three sporangia in my collection were obtained in culture, each from the bark of another kind of tree. Plasmodium watery white.

Craterium aureum (Schum.) Rost.

On dead leaves and grass; in some summers common. Plasmodium yellow. 
* Crat. auronucleatum N.E.N-B. (Acta Bot. Neerl. 10: 62. 1961)

Found only once, on dead leaves and living grass.

* Crat. concinnum Rex

Found only once, on a dead leaf in a ditch under bracken, Bilthoven. First record for Europe (cf. Acta Bot. Neerl. 10: 61. 1961).

* Crat. cylindricum Massee (C. leucocephalum (Pers.) Ditmar var. cylindricum Lister)

Found only once (leg. J. L. Nannenga) on a cap of a milkbottle between dead leaves.

Crat. leucocephalum (Pers.) Ditmar var. leucocephalum

On dead leaves and on piles of garden refuse; common. Plasmodium yellow.

Crat. leucocephalum (Pers.) Ditmar var. cylindricum Lister cf. C. cylindricum

* Crat. leucocephalum (Pers.) Ditmar var. scyphoides Lister

On dead leaves and stems of herbaceous plants; collected a few times in the same site as the typical form. Plasmodium yellow.

Crat. minutum (Leers) Fries

On dead leaves and other herbaceous matter; common. Plasmodium yellow.

Cribraria argillacea (Pers.) Pers.

On decaying coniferous wood; common. Plasmodium dark grey or blue-grey.

Crib. aurantiaca Schrad.

On decaying coniferous wood; very common. Plasmodium bright green.

* Crib. ferruginea Meylan

Collected only once, viz. on a mossy pine stump near Leersum.

Crib. intricata Schrad. ?

With considerable misgivings I place here, at least provisionally, a large number of collections of a small, nutbrown Cribraria. Their size is about two thirds of that of $C$. aurantiaca. The cup, seen by the aid of a hand lens, looks almost smooth, but under the microscope it proves to be minutely striate with striae radiating from the stipe; it is moreover provided with very delicate concentrical or more or less spiral wrinkles; its height is half to one third that of the sporangium as a whole. The nodes are large and flat; the granules of the same size as those of $C$. aurantiaca and $C$. intricata, and pale, rarely dark. The threads by which the nodes are connected with each other, do not run parallel as in $C$. intricata, but there is, as a rule, more than one connection between the nodes; some of the threads, moreover, have free ends. The spores are about $8 \mu$ in diam., minutely spinulose and also provided with warts, of which in the optical section five or six are seen on the circumference; these warts are often connected by faint rows of spinules, and then the surface of the spores looks very laxly reticulate. Plasmodium dark grey. 
* Crib. macrocarpa Schrad.

Once collected on a practically undecayed fallen pine branch and on the needles of the latter. "De Pan" near Zeist.

* Crib. microcarpa (Schrad.) Pers.

Once collected on a decaying stump, where on account of its small size it is easily overlooked. In culture it appeared on the inner side of the bark which was pealing off from a dead oak branch and on coniferous wood (also on coniferous wood taken home from Bilthoven). Plasmodium grey, turning hyaline when the very long stalks of the sporangia have been formed. At that time too the nodes make their appearance, and as the sporangium is at this stage still hyaline, they stand out very conspicuously.

Crib. rufa (Roth) Rost.

On decaying coniferous wood; common; one collection from an oak stump. Plasmodium sometimes dark grey, turning dirty white, but more often already dirty white when emerging from the wood.

Diachea leucopodia (Bull.) Rost.

On dead leaves, bramble stems, living grass and herbs; not rare. Also one collection from Elst in the Betuwe, where it was found for several weeks in considerable quantity on a heap of garden refuse, and two collections received from Dr. G. H. Boerema, who collected them on grass and on strawberry leaves at Wageningen. Plasmodium white.

* Dianema harveyi Rex

Collected several times but always in the same locality, where it occurred on fallen branches of a lime tree. Plasmodium pink.

Dictyaethalium plumbeum (Schum.) Rost.

On fallen branches; not rare. In one aethalium collected on a dead branch of Prunus laurocerasus the spore mass has a rusty colour, not the usual yellow or ochraceous tint. Plasmodium pink; in the aberrant specimen not seen.

Dictydium cancellatum (Batch) Macbride var. cancellatum

On decaying wood; common. Plasmodium black; the wood from which it emerges, sometimes stains purple.

Dictyd. cancellatum (Batch) Macbride var. fuscum Lister

On decaying wood; common. Plasmodium black.

Diderma effusum (Schw.) Morgan

On dead leaves; not rare. Plasmodium white.

* Dider. deplanatum Fries

Collected in one place only, where it returns every winter; it grows here on dead oak leaves. Plasmodium white.

Dider. floriforme (Bull.) Pers.

Only once collected, on a beech stump.

Dider. globosum Pers.

Collected only once, on dead leaves under a hazel shrub. Plasmodium white. 
Dider. hemisphaericum (Bull.) Hornem.

On dead leaves, twigs and refuse of herbs; not rare. Plasmodium white.

Dider. montanum (Meylan) Meylan

Collected only once on a small mossy stump.

* Dider. radiatum (L) Morgan var. umbilicatum Meylan

Regularly collected at two sites, where it occurred on dead twigs and on living moss. Rather similar to $D$. montanum and rather unlike $D$. radiatum var. radiatum. Plasmodium white.

Dider. spumaroides (Fries) Fries

Only two collections, one with small, scattered, grey sporangia on a hardly visible hypothallus, and one with strongly congested white sporangia inserted on a crustose, white hypothallus; both from leaves. Plasmodium of the specimen with grey sporangia white.

Dider. testaceum (Schrad.) Pers.

On dead leaves and bramble stems, sticks and living grass and herbs; not found before 1960, but then locally abundant. Plasmodium whitish.

* Dider. spec.

A small collection of pale rose sporangia provided with an angular stipe and a small and globose pink columella. I have as yet not succeeded in placing it.

Didymium anellus Morgan

Gollected only once, on a pile of herbaceous stems thrown away in a wood.

Didym. clavus (Alb. et Schw.) Rab.

On dead leaves and on bark of living trees; appearing also in cultures; common. Plasmodium grey or dirty white.

Didym. co.mplanatum Rost. cf. D. serpula

Didym. difforme (Pers.) S. F. Gray var. difforme

On decaying vegetable matter; very common. Plasmodium dirty white.

* Didym. difforme (Pers.) S. F. Gray var. comatum Lister

Here I place a number of specimens which differ considerably from $D$. difforme var. difforme, not only in the more profuse capillitium and in the paler spores, the characters mentioned in the description of the variety, but also in the closely adherent sporangium walls, the white or nearly white and rugose base of the sporangium, the very weak attachment of the capillitium to the base of the sporangium as well as to the peridium, and the subglobose, minutely reticulate spores. On account of the weak attachment of the capillitium, as soon is the lid is off, the latter comes out, in the plasmodiocarpous forms as a woolly mass, in the sporangiate ones in the form of a column which may reach a height of about ten times the diameter of the sporangium. If my specimens really are identical with those of the Listers (I did not like to touch any of the very few sporangia in the Lister collection in the British Museum), 
this variety would, in my opinion, deserve specific rank. Rests the question whether Chondrioderma calcareum Rost., which has been quoted as a synonym, is actually identical. As the type of this species does not seem to be available, it will be difficult to answer this question.

* Didym. difforme (Pers.) S. F. Gray var. repandum Lister Three collections, on dead remains of herbs.

* Didym. dubium Rost. (D. wilczeki Meylan)

Five collections only of which two are limeless, on dead herbaceous plants. May be this mainly mountainous species may be considered a relic from glacial times, like some hepatics occurring in this neighbourhood.

Didym. iridis (Ditmar) Fries (D. nigripes Fries var. xanthopus Lister) On dead leaves and grass (n. 32 was identified for me by Dr. Karstens).

Didym. megalosporum Berk. et Curt. (D. nigripes (Link) Fries var. eximium Lister)

On leaves, fallen pine needles and stems of herbaceous plants; not rare. Plasmodium yellow.

Didym. melanospermum (Pers.) Macbride

On fallen leaves, pine needles, grass, herbs and moss; common. Plasmodium dirty white.

Didym. minus (Lister) Morgan

In similar habitats as the preceding species; not rare.

Didym. nigripes (Link) Fries var. nigripes

On dead leaves, living grass and ivy; common. Plasmodium brown.

Didym. nigripes (Link) Fries var. eximium Lister cf. D. megalosporum

Didym. nigripes (Link) Fries var. xanthopus Lister cf. $D$. iridis

* Didym. ovoideum N.E.N-B. (Acta Bot. Neerl. 7: 780. 1958)

The type was collected at Bilthoven in a ditch under oak and bracken, where it yearly returns; another specimen is from Doorwerth on pea straw. Plasmodium yellow.

* Didym. serpula Fries (D. complanatum Rost.)

On dead leaves, pine needles and living grass; four collections. Plasmodium yellow.

Didym. squamulosum (Alb. et Schw.) Fries

On dead leaves, etc.; very common. Very variable in all its parts. Plasmodium pure or dirty white.

* Didym. trachysporum G. Lister

Collected once, on a pile of decaying potato plants in a beech plantation, but next to a potato field.

* Didym. vaccinum (Dur. et Mont.) Buchet

On tightly packed straw decaying in the garden, where it appeared continuously for some weeks. Plasmodium orange. Didym. wilczeki Meylan cf. D. dubium.

* Echinostelium fragile N.E.N-B. (Acta Bot. Neerl. 10: 65. 1961)

Known only from a culture of bark from a living horse- 
chestnut tree on the "Hemelse Berg" near Oosterbeek. Plasmodium watery, pale pink.

* Ech. minutum De Bary

Because of its minute size not likely to be found in the open, but very common on wood and bark in cultures. Mostly white, but pale pink and beige sporangia are also met with. Plasmodium watery.

Enerthenema papillatum (Pers.) Rost.

On dead wood; common. It appears also regularly in cultures on bark taken from living trees, and occurs in two forms, viz. one with fine, smooth, only slightly branched capillitium, and one with thick, black, much branched and spinulose capillitium. Plasmodium watery white.

Enteridium olivaceum Ehrenb.

Not rare on logs and fallen branches. Plasmodium pink. About one half of my specimens have the spores clustered, and then the latter are more spinose on the free side; in the other half the spores are free, and then the spinules are evenly distributed over the surface.

* Fuligo cinerea (Schw.) Morgan

Found only once, on dead leaves and pine needles.

Ful. septica (L) Weber var. septica

Macbride and Martin quote in their monograph several varieties of $F$. septica. In the following I will cite their diagnoses between quotation marks. The typical form is said to be "large, yellow. ochraceous or tawny, with an extremely friable, foamy cortex. The calcareous internal structure is white. The spores are spherical, nearly smooth and 6-8 $\mu$ in diam". This typical form is not common in this neighbourhood; most yellow or yellowish Fuligos tend to bleach, whereas the internal structure is usually pure yellow, and these, therefore, belong to the var. flava.

* Ful. septica (L) (Weber) var. flava Pers.

"Aethalia wide-spread, but thin, yellow or yellow green, the cortex yellow but extremely evanescent; the capillitium yellow throughout. The spores tend to average somewhat larger than those of the other varieties, 8-9 $\mu$. On fallen logs in moist dark woods". This is the most common form; it is found on tree stumps, grass and dead leaves. Plasmodium yellow.

Ful. septica (L) Weber var. candida Pers.

"Plasmodium, aethalium and limeknots white, giving the whole structure a grayish white appearance when mature". This form too is common, and is found in the same habitats as the var. flava. Plasmodium white, rarely creamy.

Ful. septica (L) Weber var. rufa Pers.

"Aethalium usually thick and rather solid; much less flattened in proportion than the typical form; the cortex is porose but firm, orange at first, becoming tawny with age, often exhibiting 
two distinct layers; the interior grayish; the spores 6-7 $\mu$. Forest". Common on stumps, less common on grass! often forming extensive aethalia. Plasmodium yellow.

* Ful. septica (L) Weber var. laevis Pers.

"Similar to the preceding, but usually smaller, with a smooth, rusty brown, persistent cortex, which remains when all the grayish sporiferous mass has been distributed. Forest"'. Only once collected.

Hemitrichia clavata (Pers.) Rost.

Two collections only; one from a decaying beech stump, the other from dead wood in the trunc of a living ash.

Hem. karstenii (Rost.) Lister?

On bark of various dead trees; not rare. Plasmodium white. This is generally considered to be no more than a form of Trichia contorta; it may be that my specimens are $\mathbf{T}$. contorta, as the capillitial net is not very pronounced.

* Hem. leiotricha Lister

Two collections only; the first, consisting of two sporangia, from the petiole of a birch leaf, the second, consisting of a few more sporangia, from a dead leaf.

Hem. minor G. Lister cf. Perichaena minor

* Hem. stipitata (Massee) Macbride

Two collections only, both on beech stumps; one by $\mathbf{M}$. A. Nannenga.

Hem. vesparium (Batsch) Macbride

On decaying tree stumps; very common. Plasmodium black. In my specimens the capillitium is but rarely branched, and this species would therefore, in my opinion, better be placed with Trichia.

Lachnobolus congestus Lister cf. Arcyodes incarnata

Lamproderma arcyrioides (Sommerf.) Rost. (L. violaceum Rost.)

Collected only once; on a decaying beech stump in winter.

* Lamp. arcyonema Rost.

One collection only, from an oak stump near Utrecht (leg.

E. T. Nannenga).

Lamp. scintillans (Berk. et Br.) Morgan

On dead leaves, twigs and pine needles and on living ivy petioles; very common. Plasmodium watery white.

Lamp. violaceum Rost. cf. $L$. arcyrioides

Leocarpus fragilis (Dicks.) Rost.

On various substrates; common. Plasmodium yellow, often becoming orange as the sporangia are taking shape.

Mostly with free spores measuring from 9 to $13 \mu$ in diam.; in two collections the spores are circ. $17 \mu$ in diam., whereas in one collection (Groningen, leg. E. A. Agsteribbe) they are clustered.

* Licea biforis Morgan 
Obtained twice from bark of living trees in cultures; viz. once from that of a beech near the "Plasmolen", Mook, and once from that of a horse-chestnut on the "Hemelse Berg" near Oosterbeek. With these findings the Netherlands become. the third country in Europe from which this species is known: Rostafinsky recorded it for Poland, Alexopoulos (Brittonia 10: 26. 1959) for Greece. Plasmodium dark opaque brown.

* Lic. castanea G. Lister

Collected several times during the winter in the same place, on the bark of a felled elm, mostly on its inner side; also on bark of this tree in culture. Plasmodium yellow-brown.

Lic. fexuosa Pers. cf. L. variabilis

Lic. minima Fries

In most cultures in due time small black Liceas appear. Whether all of these may be referred to L. minima and to $L$. pusilla, is dubious. However, there are in my collection two groups either of which may perhaps be placed in L. minima. The first consists of specimens from decaying pine wood; their spores are pale red-brown and about $12 \mu$ in diam. This seems to agree well with the original description of Fries, who called them "rubiginose". Lister describes the spores as olivaceous-brown or lilac-brown, but he does not say in what condition he studied them. The red spores of the specimens of this group turn olivaceous in dilute $\mathrm{KOH}$, and this may have been the condition in which they were studied by Lister. The second group was obtained from the bark of dead fruit trees; here the spores are grey, and measure circ. $13 \mu$ in diam., and they are rather coarsely warted, whereas those of the first group are merely spinulose, and the peridium fragments are not undulate or red-brown as in the latter, but flat and yellow-brown. The exact position of these taxa will be difficult to determine, but provisionally they may be placed under L. minima. They were collected a few times in the open, but on account of their small size, they are easily overlooked.

* Lic. operculata (Wingate) G. W. Martin (Orcadella operculata Wingate) Obtained several times from bark of the same lime tree in culture. Plasmodium dirty yellow.

* Lic. parasitica (Zukal). G. W. Martin

Appears regularly on bark from living trees in cultures.

Plasmodium yellow-brown, gelatinous.

* Lic. pusilla Schrad.

Described as being chestnut-brown with large spores which are very dark in mass, and as appearing on coniferous wood. In cultures on decaying coniferous wood I obtain regularly small black Liceas to which this description applies very well. The spores are about $17 \mu$ in diam., and dark brown. The sporangium wall is dark with included matter, but yellowish brown by transmitted light. However, the undulate edges described by Lister and by Hagelstein for $L$. pusilla are absent 
in the specimens I myself place here, whereas they are a constant feature of one of the groups of specimens I have provisionally placed under $L$. minima. The question of the identity of the specimens described by Fries and Schrader will be difficult to decide!

Lic. variabilis Schrad. (L. flexuosa Pers.)

In autumn and winter on decaying coniferous wood; common. Plasmodium pinkish, turning yellowish.

- Lic. spec.

The minute sporangia of this species were obtained in culture on bark of living elm, lime and oak covered by moss. It resembles to some extent $L$. fimicola, but the sporangia are brown, strongly depressed, oval in outline and provided with a dark rim of granular matter round the base. The number of sporangia appearing at a time is but small. Comparison with the type of L. fimicola, kindly sent by Dr. G. W. Martin, proves the two to be distinct: the spores, although smooth or nearly so, are appreciably smaller in my specimens.

Lycogala conicum Pers.

Collected three times on decaying beech stumps, twice in the vicinity of Doorwerth and once at the "Plasmolen" near Mook; the last-mentioned specimen, unfortunately, has been lost. Plasmodium pink.

Lyc. epidendrum (L) Fries

On decaying wood; very common. Plasmodia either orange-red to vermilion or carmine; in the first case the aethalia become beige, in the second dark grey-brown.

Lyc. flavofuscum (Ehrenb.) Rost.

On rotting wood parts in living trees, especially in beech * Lyc. spec.

(one collection from birch); not rare. Plasmodium white.

At Doorwerth once a small aethalium was found on pine needles. The cortex was very thin, transparent and evanescent; the pseudocapillitium consisted of tubules with a rather narrow lumen and with large constrictions; the spores were in mass as well as by transmitted light pale rose. The material does not seem sufficient for the description of a new species, but perhaps more may be found.

\section{Margarita metallica (Berk.) Lister var. metallica}

Once a few sporangia were found on grass, but it often appears on bark in cultures, especially in winter. Plasmodium pink or white:

Marg. metallica (Berk.) Lister var. plasmodiocarpa R. E. Fries Collected once on the bark of a living horse-chestnut at Schaloen, South Limburg. Plasmodium pink.

Mucilago spongiosa (Leysser) Morgan

Twice collected by $E$. $T$. Nannenga on grass, once on a roadside at Doorwerth, and once from the base of a dike at 
Elden, in the Betuwe. From Dr. G. H. Boerema I received two specimens collected at Wageningen, also on grass.

* Oligonema flavidum (Peck) Peck

On a decaying beech stump in an exposed position, where it returned for several years.

Orcadella operculata Wingate cf. Licea operculata

Perichaena corticalis (Batsch) Rost.

On bark of dead trees; not rare. Plasmodium grey.

Per. depressa Lipert

On bark of dead trees; not rare. Plasmodium wine-red.

* Per. minor (G. Lister) Hagelstein (Hemitrichia minor G. Lister)

On decaying vegetable matter, twigs and branches; not rare.

Per. vermicularis (Schw.) Rost.

On decaying vegetable matter; not rare.

Physarum auriscalpium Cooke

Two small collections from nearly the same spot; on bark fallen from a dead fruit tree.

Phys. bethelii Macbride ( $P$. viride Pers. var. bethelii G. Lister)

On decaying pine stumps; common; one collection from Bilthoven. Plasmodium yellow.

Most of my specimens have longer stalks than the type specimen; however, I have also specimens in which the sporangia are partly sessile and partly stalked, with every gradation between. The species is nevertheless easily recognizable, as it has a facies of its own, viz. a dull gloss, a dimple on the top, and umbilicate at the base, all very striking features. It seems to have been collected but rarely; there are only three specimens in the Lister collection, none, as far as I know, in that of Howard (at least not in the part which is in the British Museum), and in America the situation is much the same, i.e. also three collections at the University of Iowa. It was known so far only from Colorado, Washington and Roumania; so that this is the second record for Europe. One of my specimens was identified by Dr. Karstens, and included in his list, although with a question mark; later Dr. G. W. Martin studied my number 1634, and referred it to this species; he has remeasured the spores of the type, and found them to be 12.5-13.5 $\mu$ in diam.; those of my specimen are about $12 \mu$. I would like to thank here both Prof. Karstens and Prof. Martin for their kind help.

Phys. bitectum G. Lister

On dead leaves and straw; not rare. Plasmodium white.

Phys. bivalve Pers. (P. sinuosum Weinm.)

On dead leaves and twigs; not rare. Plasmodium white.

Phys. cinereum (Batsch) Pers.

On dead leaves, living grass and herbs; common. Abundant in some summers. Very variable. Plasmodium usually white, sometimes pale yellow. 
Phys. citrinellum Peck cf. P. flavidum

Phys. compressum Alb. et Schw.

On straw and on rotting vegetable matter in general; common. Plasmodium white.

- Phys. confertum Macbride

Twice collected; once on dead leaves, and once on living grass. Plasmodium pale yellow.

Phys. connatum Lister cf. $P$. notabile

Phys. contextum (Pers.) Pers.

On dead leaves and sticks; not rare. Nearly white, yellow and orange. Plasmodium yellow.

* Phys. didermoides (Pers.) Rost.

A specimen was given to me by Dr. J. C. Sobels, who obtained it in culture from spores from a collection made by Dr. P.S. J. Schure niar Leiden.

* Phys. didermoides (Pers.) Rost. var. lividum Lister

Twice collected, once on rotting potato stems, the other time on pine needles.

* Phys. flavidum (Peck) Peck (P. citrinellum Peck)

Once collected on a dead leaf, where it occurred in company of Craterium aureum. Plasmodium yellow.

* Phys. lateritium (Berk. et Rav.) Morgan

Collected once on dead oak leaves.

Phys. leucophaeum Fries ( $P$. nutans Pers. subsp. leucophaeum Lister)

On dead wood; very common. Plasmodium greyish-white.

* Phys. mucosum N.E.N-B. (Acta Bot. Neerl. 7: 782. 1958)

Twice collected, on dead leaves and sticks. Plasmodium vellow.

* Phys. murinum Lister

Especially on pine wood; not rare. Plasmodium opaque, pale yellow.

The specimens I place here, are in fact more or less intermediate between $P$. globuliferum (Bull.) Pers. and $P$. murinum. In my specimens the peridium is rich in pale fawn or beige coloured lime scales, the lime-knots are pale yellowish-brown, and the stipe is short. In the Lister collection I came across a specimen (BM 2101) which resembled those of mine; it was placed with $P$. globuliferum, but with the note: "near $P$. murinum".

Phys. notabile Macbride ( $P$. connatum Lister)

Once collected; on a tree stump.

Phys. nutans Pers. var. nutans

On wood, leaves and pine needles a slender long-stalked form is found, which shows a strong resemblance to $P$. viride, but which is slightly larger and without any trace of yellow; on wood a second form is found in which the sporangia are more nearly globose and provided with a shorter stalk, resembling the figure which in Lister is given for the species (3rd ed. Fig. 37d); very common. Plasmodium grey, turning white or pale yellow as the sporangia are taking shape. 
Phys. nutans Pers. var. leucophaeum Lister cf. P. leucophaeum

Phys. nutans Pers. var. robustum Lister

On dead wood; very common. Plasmodium grey, turning white or pale yellow as the sporangia are formed.

Phys. psittacinum Ditmar

Only once collected, on the bark of a fallen oak branch. Plasmodium orange.

Phys. sinuosum Weinm. cf. $P$. bivalve

Phys. straminipes Lister ?

Collected only once, on a box of rotting cherries from the year before. Plasmodium white.

The spores are very dark and distinctly facetted, and measure 13-14 $\mu$ in diam., which is rather large for this species, and the capillitium is badhamioid, which also looks unusual.

Phys. vernum Fries

On straw, hay and dead leaves; a few collections only. Plasmodium white.

Phys. virescens Ditmar

On moss, grass and leaves in open woods; common. Plasmodium yellow.

Phys. viride (Bull.) Pers. var. viride

On dead wood and twigs; very common. Plasmodium yellow.

Phys. viride (Bull.) Pers. var. aurantium (Bull.) Lister

On dead wood; common. Plasmodium orange.

Phys. viride (Bull.) Pers. var. bethelii G. Lister cf. $P$. bethelii

* Reticularia intermedia N.E.N-B. (Acta Bot. Neerl. 7: 773. 1958)

Collected a few times on dead beech branches, "Boersberg", Doorwerth.

* Ret. jurana Meylan (R. lycoperdon Bull. var. jurana G. Lister)

On decaying wood; very common. Plasmodium first white, then rose, beige and dark brown; the rose stage but rarely evident.

Ret. lycoperdon Bull. var. lycoperdon

On dead wood; common. Plasmodium white.

Ret. lycoperdon Bull. var. jurana G. Lister cf. R. jurana

Stemonitis axifera (Bull.) Macbride (S. ferruginea Ehrenb.)

On dead wood; very common. Plasmodium white.

Stem. confuens Cooke et Ellis

The description of this species given by the Listers and that given by Macbride and Martin differ in various points. My own specimens, all from bark pealing off from a dead fruit tree, and mostly from the inner side of the bark, agree very well with the description given by Macbride and Martin, for they are sooty black and provided with very dark spores, measuring 13-14 $\mu$ in diam. Although I have been on the lookout for the plasmodium, and have gathered the species time and again, I have never seen it. According to Lister as 
well as to Macbride and Martin it would be white, but I can hardly believe that the specimens collected by me can have shown such a conspicuous tint in any stage.

Stem. flavogenita Jahn

On dead wood, and sometimes on twigs and dead leaves; common. Plasmodium yellow.

Stem. fusca Roth var. fusca

On dead wood; very common. Very variable. Plasmodium white.

Stem. fusca Roth var. confluens Lister

On dead wood, thick fallen branches and tree stumps; not rare. Plasmodium white.

The plasmodia are usually large, and they often leave the wood to form the sporangia on grass and dead leaves in the neighbourhood. It shows no very close resemblance to the typical $S$. fusca, for the sporangia are short, closely set, practically sessile, of a darker dusky brown or nearly black colour, and the hypothallus forms ridges round the base of the sporangia. As the peripheral net is lacking, it would perhaps be better to transfer it to Comatricha, as has been done with Stem. splendens var. flaccida (cf. Comatricha flaccida).

Stem. herbatica Peck

Among my specimens which answer the description of this species, two groups are represented; those of the first group are tall, over $1 \mathrm{~cm}$ high; these grow in tufts on dead wood; the other ones are shorter, not exceeding $0.7 \mathrm{~mm}$, more densely tufted with the tufts standing close together; these are found on grass and dead leaves. In the specimens growing on wood the plasmodium is white or yellow, in the other ones always white.

Stem. hyperopta Meylan var. hyperopta

On dead coniferous wood; common. Plasmodium white.

This species is easily recognizable, because it is of a colour which is most unusual in this genus, viz. pale lilac-rosy; in time, however, the sporangia darken, although they always retain a trace of the original lilac colour. The spores have a very characteristic but faint reticulation, with a small mesh where the spores touch each other in the sporangium, and larger, often elongate meshes in between.

As the surface net is present only in the basal part of the sporangium, and as it is even here often incomplete, this species might be placed equally well with Comatricha, a fact which in the beginning caused me a good deal of trouble. My first collections were identified by Dr. Karstens.

* Stem. hyperopta Meylan var. microspora Lister

Two collections from wood; these are much like the typical form; one from dead leaves and living grass; here the sporangia are more conical than in the typical form.

Stem. pallida Wingate? 
With some hesitation I place here one sporangium from a large beech stump, and a small collection from an oak branch.

Stem. splendens Rost. var. flaccida Lister cf. Comatricha flaccida

* Stem. smithii Macbride

On dead wood; common. Plasmodium white.

Much like $S$. axifera, but differing in the cinnamon-brown colour of the sporangium and the smaller size of the spores. Stem. trechispora (Torrend) Macbride ?

Here I place, although perhaps erroneously, some sporangia found in tufts on leaves; the spores are beautifully bandedreticulate; further study is necessary. Plasmodium white.

* Stem. spec. ?

A very dark, almost black Myxomycete, twice collected. The sporangia are closely appressed, more or less like those of $S$. fusca var. confluens, with little or no surface net; the columellas weak and crooked or wanting; the capillitium wide-meshed, very dark; the spores very conspicuously marked with a broken, banded reticulation. Parts of the peridium prove to be persistent, and show faint dashlike marks. Dr. Martin suggests that it may be an Amaurochaete, but the presence of peridium parts between the sporangia seems to contradict this. It might perhaps find a place in Comatricha, in the vicinity of C. flaccida. I hope to return to this species at another occasion, when it has been studied more fully.

Trichia botrytis (J. F. Gmel.) Pers. var. botrytis

In autumn and winter on decaying wood; common. Plasmodium black.

* Trich. botrytis (J. F. Gmel.) Pers. var. munda Lister

Once collected on a leaf. Plasmodium brown.

The collection consists of a very small number of sporangia; the latter are minute and brownish-yellow.

* Trich. botrytis (J. F. Gmel.) Pers. var. flavicoma Lister

Once found, in a culture on bark taken from a living willow at Schaloen, South Limburg. Plasmodium white.

Trich. contorta (Ditmar) Rost. (in this species I include $T$. inconspicua Rost.)

On bark and wood of dead trees; not rare. Plasmodium yellow-brown.

It seems to me that $T$. contorta, at least as interpreted by Lister, is no more than an abnormally developed $\mathcal{T}$. inconspicua. I am inclined to enclude in this species also Hemitrichia karstenii, as in the latter plasmodiocarpous forms often occur side by side with sporangiate ones, and as in the plasmodiocarpous forms the anastomising elaters are, as a rule, neither very conspicuous nor numerous, at least in the specimens I have doubtfully refered there.

Trich. decipiens Macbride cf. T. pusilla 
Trich. favoginea (Batsch) Pers.

Four collections from tree stumps. Plasmodium yellow.

Mrs M. L. FARR (Mycologia 50: 357-369. 1958) has united $T$. persimilis, $T$. affinis and $T$. favoginea to one species, as in her opinion, based on a study of a large number of specimens, they merge one into the other. However, as there are in my material no transitions at all between $\mathcal{T}$. persimilis and $T$. flavoginea, I have kept them apart.

* Trich. floriformis (Schw.) G. Lister

One collection from a beech stump in the park "Hoge Veluwe". Trich. persimilis Karst.

On dead wood; common. Plasmodium white.

See the remark made under $T$. favoginea.

Trich. pusilla (Hedw.) G. W. Martin ( $\mathcal{T}$. decipiens Macbride) On decaying wood; common. Plasmodium white or pink.

Trich. scabra Rost.

On decaying wood and sometimes on straw; very common. Plasmodium white.

Trich. varia (Pers.) Rost.

On dead wood and bark; very common; more rarely on leaves. Plasmodium white.

Trich. verrucosa Berk.

A few collections only, among others in several consecutive years from a hole in an oak stump. Plasmodium white.

Tubifera ferruginosa (Batsch) F. J. Gmel.

On decaying wood; very common. Plasmodium orange or salmon-coloured.

In the sporangia composing the pseudoaethalium I often find pseudocapillitium, rigid tubes or (and) pseudocolumellae. 